\title{
"Assessing multisensory attributes of malt drinks and consumer purchase decisions in South-Eastern Nigeria"
}

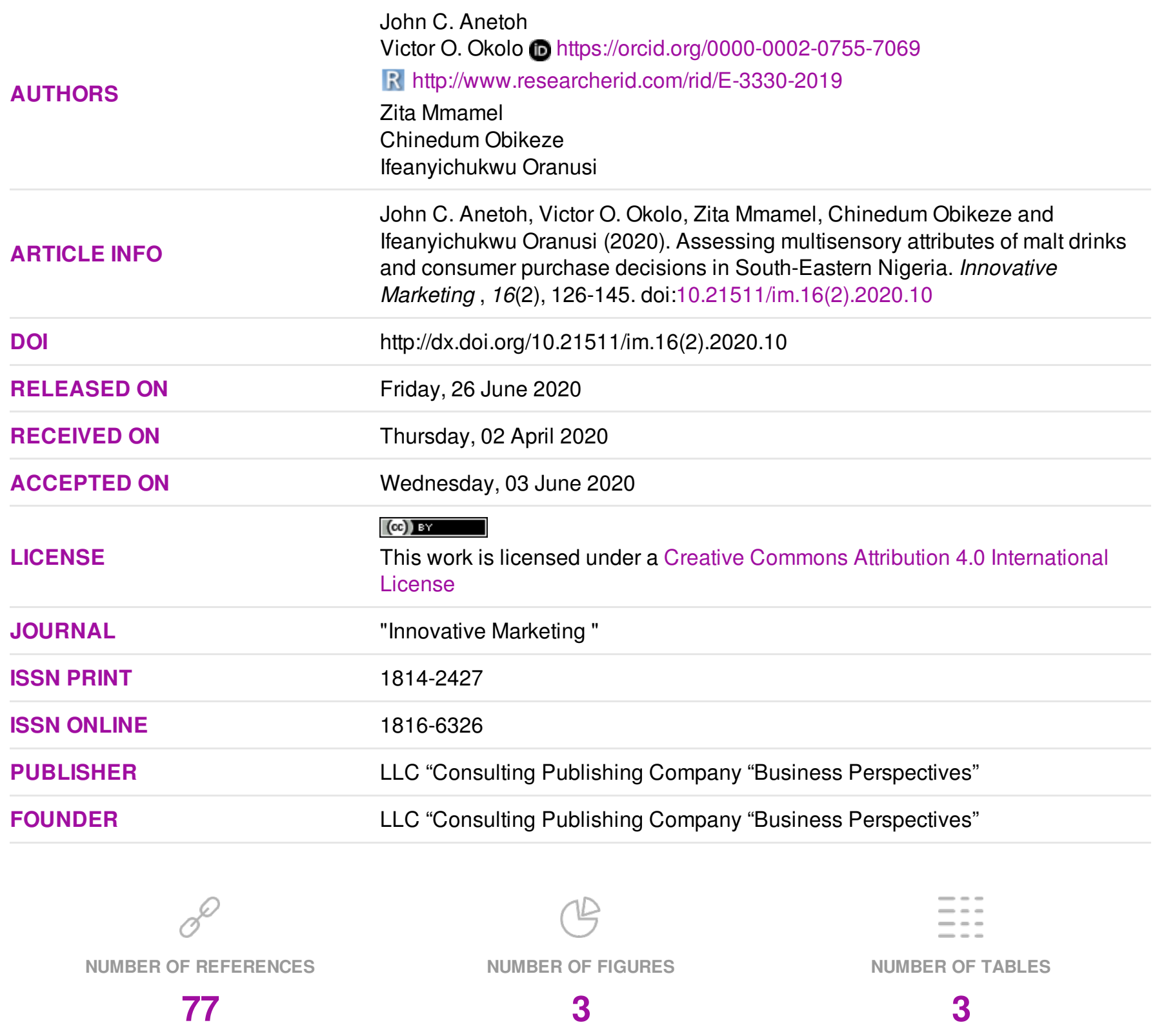

(C) The author(s) 2023. This publication is an open access article. 


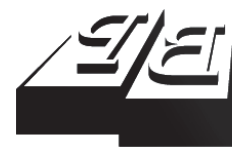

\section{BUSINESS PERSPECTIVES}

9

LLC "CPC "Business Perspectives" Hryhorii Skovoroda lane, 10, Sumy, 40022, Ukraine www.businessperspectives.org
Received on: $2^{\text {nd }}$ of April, 2020 Accepted on: $3^{\text {rd }}$ of June, 2020 Published on: $26^{\text {th }}$ of June, 2020

(C) John Anetoh, Victor Okolo, Zita Mmamel, Chinedum Obikeze, Ifeanyichukwu Oranusi, 2020

John Anetoh, M.Sc., Lecturer I, Department of Marketing, Chukwuemeka Odumegwu Ojukwu Universiy, Igbariam Campus, Nigeria.

Victor Okolo, M.Sc., Lecturer I, Department of Marketing, University of Nigeria Nsukka, Enugu Campus, Nigeria. (Corresponding author)

Zita Mmamel, Ph.D., Chief Lecturer, Department of Marketing, Institute of Management and Technology, Enugu, Nigeria.

Chinedum Obikeze, Ph.D., Senior Lecturer, Department of Marketing, Chukwuemeka Odumegwu Ojukwu University, Igbariam Campus, Nigeria.

Ifeanyichukwu Oranusi, Ph.D., Lecturer II, Department of Marketing, Nnamdi Azikiwe University, Awka, Nigeria.

John Anetoh (Nigeria), Victor Okolo (Nigeria), Zita Mmamel (Nigeria), Chinedum Obikeze (Nigeria), Ifeanyichukwu Oranusi (Nigeria)

\title{
ASSESSING MULTISENSORY ATTRIBUTES OF MALT DRINKS AND CONSUMER PURCHASE DECISIONS IN SOUTH-EASTERN NIGERIA
}

\begin{abstract}
Competition has increased due to the proliferation of different brands of malt drinks in Nigeria. Thus, manufacturers and brand managers of malt drinks need to explore strategic approaches to acquiring and retaining their customers. However, this paper assessed the multisensory attributes of malt drinks and consumer purchase decisions in South-Eastern Nigeria. The study population comprises consumers of Maltina, Malta Guinness, Amstel Malta, Dubic Malt, and Grand Malt in South-Eastern Nigeria. A sample size of 384 consumers of malt brands was determined using Topman formula. A convenience sampling technique was adopted, and respondents were drawn from five states such as Abia, Anambra, Ebonyi, Enugu, and Imo. The study adopted a cross-sectional survey research method. Cronbach's alpha and composite reliability were estimated to check the internal consistency of the study constructs. The structural equation modeling technique was used in data analysis. Findings revealed that the visual attribute of malt has a significant positive relationship with consumer purchase decisions. It was also revealed that malt brand gustatory attribute has a significant positive relationship with consumer purchase decisions. Similarly, it was revealed that the tactile attribute of malt brand has a significant positive relationship with consumer purchase decisions. Finally, it was revealed that the malt brand olfactory attribute has a significant positive relationship with consumer purchase decisions. Therefore, manufacturers and brand managers of malt should improve on packaging their malt brands by strategically adapting a multisensory synergy to guarantee wider consumer purchase and experience toward ensuring more customer satisfaction, patronage, and increased profits for the organizations.
\end{abstract}

\section{Keywords}

JEL Classification

\section{INTRODUCTION}

Surviving the challenges posed by the marketing environment had been highly dynamic and competitive. Hence, only customer-centric companies can become a "Victor." However, consumer behavior is a roller coaster, which consequently thrusts enormous responsibility on organizations to understudy the consumers and evolve a strategic and sustainable method of satisfying and delighting them in all their needs. It automatically became germane for companies to gain adequate information and knowledge about the consumers to understand their behavior and what spurs them into purchase action. Most importantly, manufacturers and brand managers have deployed various media channels to offer incessant advertising bombardments to influence consumer behavior. Interestingly, making a purchase decisions for contemporary consumers had become more complicated as there are many different products and brands of products, which they pursue. 
Unequivocally, satisfying consumers had become crucial and critical to most organizations as consumers have acquired enough information and education, grown wiser, more advanced, savvy, and sophisticated about the products they choose to buy (Okolo, 2017). Therefore, the understanding of consumer behavior, though enigmatic, is very indispensable to the success and longevity of both the consumers and marketing organizations. Without the consumers, there is no market, no marketing, no business, no economic growth, and ultimately, no sustainability.

However, five human senses are indisputably fundamental to consumer purchase and consumption experience. These senses converge in the human brain to perceive objects, form ideas, and decide about products and services. It is unquestionably a synergistic behavior; hence, one sense organ is affected by the other sense organs. So, multisensory product attributes play an important role in influencing purchase decisions. Pragmatically, the indispensability of the deployment of the consumer's five senses in making a purchase decision cannot be underestimated. Most times, the consumer needs to hear (auditory) in order to see (visual), needs to touch (tactile) in order to smell (olfaction), and needs to smell in order to taste (gustatory). All these are judicious trajectories woven into the manufacture of a product to control the consumer's senses toward eliciting product trial and repurchase behavior. Emphatically, none of these senses need to be in isolation in packaging products for consumers; otherwise, they may not perceive the product holistically while making a purchase decision. Hence, the integration of all five senses is highly relevant to ensure that the consumer never sees an escape route toward rejecting a product or service. Different brands of products can only be differentiated through these senses, and that is the realm in which marketers strategically manage and position their brands alongside multisensory product attributes - smell, touch, sight, taste, hear, or sound.

Nevertheless, perception is universally multisensory and never uni-sensory as the brain-controlled sense organs stimulate consumers. Thus, because customers generally establish a deeper attachment with a product through multisensory appeal, they consider how the product is perceived when it is tasted, when it is seen, when it is touched, when it is smelled, and when it is heard during purchase. Indisputably, the autonomous and independent functioning of the different sense organs in isolation is abnormal. Therefore, consumer's brand perception, association, and purchase experience through multisensory synergy becomes very logical and germane. Pramudya and Seo (2019) highlighted that although there is the interdependency of the multisensory perception and adoption of a product or brand, they may at different situations possess dominance over each other in consumer perception, evaluation, purchase, and consumption, or usage of that particular product or brand. Rodrigues, Hulten, and Brito (2011) submitted that as consumers are inextricable to multisensory brand association and experience, every marketing offering must be focused on them in a unique and specific manner.

Based on previous studies on the relationships between multisensory variables and consumers' purchase decisions, there are still contradictions in the literature (Ray \& Shiny, 2017). Therefore, further empirical justification is needed to support or refute these previous scholars' findings on the nature of the relationships between visual, gustatory, tactile, and olfactory product attributes and consumer purchase decisions. Consequently, and based on the available literature, it was discovered that no study in Nigeria to the best of the researchers' knowledge has dwelt with assessing the extent of the relationship between multisensory attributes of malt drinks and consumer purchase decisions. Thus, to close this gap in the literature, this study is significant and seeks to satisfy many stakeholders, especially in the beverage industry.

\section{Research aims}

This study has a high trajectory in stimulating the awareness and commitment of manufacturers and brand managers about the consciousness of consumers' five senses and how they contribute profoundly to consumer purchase decisions. Therefore, the focus is for manufacturers and brand managers to incorporate the extrinsic and intrinsic multisensory product attributes in developing and packaging 
their products to their various stakeholders. Also, this study will expose consumers to be mentally alert and capable of perceiving the multisensory attributes each time they want to make a purchase decision. Consumers will out of their own volition and wisdom make a rational and logical effort by embarking on multisensory perception with great anticipation that this will improve their satisfaction through favorable purchase decisions.

\section{Objectives of the study}

The main objective of this research is to assess the relationship between multisensory attributes of malt brands and consumer purchase decisions. The specific objectives of this study are:

1. To investigate the relationship between the malt brand visual attribute and consumer purchase decision.

2. To examine the relationship between the malt brand gustatory attribute and consumer purchase decision.

3. To determine the relationship between the malt brand tactile attribute and consumer purchase decision.

4. To assess the relationship between the malt brand olfactory attribute and consumer purchase decision.

\section{Research questions}

Based on the objectives of this study, the following research questions were raised:

1. What is the extent of the relationship between malt brand visual attribute and consumer purchase decision?

2. What is the extent of the relationship between malt brand gustatory attribute and consumer purchase decision?

3. What is the extent of the relationship between malt brand tactile attribute and consumer purchase decision?

4. What is the extent of the relationship between malt brand olfactory attribute and consumer purchase decision?

\section{LITERATURE REVIEW AND HYPOTHESES DEVELOPMENT}

\subsection{Multisensory product attributes}

Multisensory product attributes are features of a product (malt) assessed through the human sense organs. Visual product attribute is concerned with sight. Malt drink visual attributes include the color, size, shape, appearance, and design of the bottles, packs, and cans (Latasha et al., 2016). Besides, gustatory product attribute is associated with taste. Malt gustatory attributes include low sugar content, the quality taste, sweetness of malt, the sucrose, and the creamy content (Raj \& Shiny, 2017). The tactile product attribute is associated with touch. Malt tactile attributes include the weight, chillness, smoothness, glossiness, and feel of the bottles, packs, and cans (Balaji, Srividya, \& Subhash, 2011). Olfactory product attribute is associated with the smell or olfaction. Olfaction is a very important factor in product evaluation, overall experience, and purchase decisions (Anggie \& Haryanto, 2011). Malt olfactory attributes include flavor, aroma, fragrance, pleasant odor, and a nice smell (Onyango, Luvitaa, Unbehend, \& Haase, 2020).

\subsection{Consumer purchase decision}

Consumer purchase decision is a consumer's absolute resolution to evaluate and choose a product or brand from several alternatives (Imiru, 2017; 
Khuong \& Duyen, 2016). It refers to the decision to purchase or not to purchase a particular brand of a product after evaluating the product attributes (Kotler, Armstrong, \& Opresnik, 2018; Ngoroge, 2017). Interestingly, consumer purchase decision entails the process to which a consumer assesses many brands of a product category and its alternatives based on the strength of various attributes and eventually purchases the brand that appeals to his or her senses (Oghojafor, Adeosun, \& Ganiyu, 2013). Succinctly, the actual purchase decision is the stage to which a consumer's purchase intention turned to actual purchase action. Moreover, consumers majorly make purchase decisions while associating their sensory and perceptual stimuli towards the products (Cortina-Mercado, 2017). In addition, sensory product attributes not only facilitate consumer purchase intention but also influence the actual purchase decisions or actions, which result in consumer satisfaction (Kotler, 2014).

In addition, consumer purchase decisions can also be influenced by online marketing cues (Vijay, Thoppan, Nathan, \& Fekete, 2019; Jenyo \& Soyoye, 2015). Abari and Safitri (2018) revealed that purchase decision is influenced by brand image and price. Surprisingly, a study conducted by Hanaysha (2017) revealed varied findings. While consumer purchase decisions had a significant positive effect on corporate social responsibility construct, sales promotion; on the other hand, had a negative effect on consumer purchase decisions. Amankwah (2016) revealed that the quality of nestle products in Ghana influences consumer purchase decisions. On the other hand, Hanaysha (2017) in his findings also revealed that social media influence on purchase decisions concerning retail sales in Malaysia was not significant. Another study revealed that packaging color and packaging materials had no relationship with consumer purchase decisions (Imiru, 2017).

\subsection{Visual attribute and consumer purchase decision}

Sight is an important cue and a major factor required during product evaluation and actual purchase (Steinhauser, Janssen, \& Hamm, 2019). Visual evaluation of product attributes leads to overall consumer experience and purchase ac- tion (Cortina-Mercado, 2017). Product design and appearance enforce emotions and consumer responses as they create the willingness to purchase a product (Mertens, Hahnel, \& Brosch, 2020). Similarly, product color leads to positive consumer purchase actions. Certainly, product appearance plays an important role and also drives the consumer's adoption of a product (Wei, Singgih, Woods, \& Adar, 2013). A product design, color, size, and shape are associated with consumer purchase of products, especially malt drinks (Ngoroje, 2017). Ozcan, Cupchik, and Schifferstein (2017) found that visual perceptions influence consumer associations with a product. Interestingly, product appearance, manufacturing date, and expiry date, nutritional information, eco-labeling, and packaging affect consumer purchase decisions (Zia, 2017; Schnettler, Miranda, Lobos, Sepulveda, Orellana, Mora, \& Grunert, 2015). Previous studies revealed that consumer latitude of acceptance and purchase of a product directly affects the visual attractiveness (Parnamets, Johansson, Gidlöf, \& Wallin, 2016). Given this statement, Gere et al. (2016) submitted that consumer food choice is determined by its visual attention, although product size, appearance, color, shape, and design, which represent the visual attributes, are essential in product evaluations and brand choices (Halabi \& Hands, 2018). Arguably, what is the extent of the relationship between malt brand visual attribute and consumer purchase decision? To answer this question, the researchers tentatively state that:

H1: There is a significant positive relationship between malt brand visual attribute and consumer purchase decision.

\subsection{Gustatory attribute and consumer purchase decision}

Consumer satisfaction is championed by the taste of a product (Torquati, Tempesta, Vecchiato, \& Venanzi, 2018). Malt taste positively correlates with consumer purchase decisions in a research conducted at Kanyakumari district (Raj \& Shiny, 2017). Undeniably, taste is an essential and fundamental sensory attribute of a product (Kathuria \& Gill, 2013). Taste components, namely sweet, savor, bitter, juice, cream, salt, sucrose, fructose, and sugar are associated with consumers' purchase of a product (Redondo, Gomez-Martinez, \& Marcos, 
2014). Similarly, Van Wymelbeke, BeridotTherond, de La Gueronniere, and Fantino (2014) reported that beverages containing sucrose or intense sweeteners are associated with, and influence purchase and consumption behaviors. Moreover, Malik, Schulze, and Hu (2016) observed that intake of sugar-sweetened beverages, especially malt, is associated with weight acquisition. Besides, Kraus (2015) reported that taste determines the sensory impressions of food and drinks. In their opinion, Thompson et al. (2010) narrated that low sugar and creamy taste are related to consumer purchase of beverage products. Undoubtedly, consumer purchase and consumption behavior are driven by gustatory characteristics (Kampfer, Leischnig, Ivens, \& Spence, 2017). Therefore, what is the extent of the relationship between malt brand gustatory attribute and consumer purchase decision? To answer this question, the researchers tentatively state that:

H2: There is a significant positive relationship between malt brand gustatory attribute and consumer purchase decisions.

\subsection{Tactile attribute and consumer purchase decision}

The tactile attribute of a product also influences consumer purchase decisions (Gallace \& Spence, 2014). Tactile attribute focuses on product physical attention that leads to consumer purchase evaluation and action (Bulsara \& Trivedi, 2016). The way a product is produced is influenced by its tactile characteristics (Dubenova \& Koch, 2019). Tactile product qualities trigger a consumer's mindset; therefore, consumers evaluate the product's tactile attributes and gather relevant information about them (Eriksson \& Larsson, 2011) and their features. Balaji et al. (2011) noted that product evaluations are facilitated through the consumer's sense of touch. Grohmann, Spangenberg, and Sprott (2007) found that tactile product attribute has a significant relationship with consumer purchase of a product. Product texture also provides the customer with an experience that can never be underestimated (Krishna, Cian, \& Aydinoglu, 2017). Also, touching a product during evaluation decreases doubt (Cano, Perry, Ashman, \& Waite, 2017) and increases the actual purchase of the product (Streicher \& Estes, 2015).
In fact, the more a consumers grab a product, the more likely they would want to pay for the product. Nonetheless, Saariluomaand and Jokinen (2014) observed that consumers could boycott a product after feeling tactile dissonance. Zhang, Chen, Guo, Liu, Su, Guan, and Zhu (2016) found a correlation between a product and its tactile cues. Similarly, Wang and $\mathrm{Wu}$ (2017) found that a product's tactile characteristics has a significant positive association with consumer purchase decisions. Based on these narrations, what is the extent of the relationship between malt brand tactile attribute and consumer purchase decision? To answer this question, the researchers tentatively hypothesize that:

H3: There is a significant positive relationship between malt brand tactile attribute and consumer purchase decisions.

\subsection{Olfactory attribute and consumer purchase decision}

Interestingly, researchers have contended that flavor, pleasant odor, aroma, and congruent scent significantly influence consumer purchase of a product (Spangenberg, Grohmann, \& Sprott, 2005). Conversely, researchers revealed that olfactory properties have minor, indirect, and insignificant relationship with consumer purchase behavior (Gueguen \& Petr, 2006). In truism, product olfaction affects consumer purchase decisions (Spence, 2015). Chatterjee (2017) maintained that product odor and nice smell have positive relationships with consumer purchase behavior. Similarly, good product olfaction triggers the memory and substantiates product value (Krishna et al., 2017). Wurz et al. (2017) conducted a study to determine if women have a better olfactory perception of wine aromas, and their findings revealed that there are differences in wine aromatic perception as the female folks were more sensitive to identify wine aroma than their male counterpart. Furthermore, ambient scent affects consumer purchase decisions (Pezoldt, Michaelis, Roschk, \& Geigenmueller, 2014). Chatterjee (2017) found that product fragrance is essentially used in the store to guard consumer choice of products. In the same vein, Meng (2016) remarked that an ambient scent affects consumer purchase decisions. Flavor perception requires olfactory messages (Samuelson \& Fontainini, 2017). Also, olfactory marketing 
has a significant influence on consumer loyalty (Mesquita \& Marques, 2013). Product olfaction and scent enhance the evaluation of products and store atmosphere (Spangenberg et al., 2005). Some managers improve brand differentiation through olfaction to guarantee consumer purchase decisions (Chatterjee, 2017). Having said this, what extent does malt brand olfactory attribute relate to consumer purchase decisions? Therefore, to answer this question, the researchers tentatively postulate that:

H4: There is a significant positive relationship between malt brand olfactory attribute and consumer purchase decisions.

\subsection{Related theories}

\section{a. The senses theory}

As propounded by Parimala (2014), the senses theory acknowledged that one can evaluate a product attribute based on the visual, gustatory, auditory, tactile, and olfactory senses. According to this theory, a consumer may evaluate a product attribute using single sensory or multisensory modal- ities. This theory assumes that when a consumer or a prospect evaluates a product by vision, taste, sound, smell, and texture, it is a single sensory assessment or evaluation. On the other hand, when evaluating a product involves the interaction or integration of five senses, it is a multisensory evaluation of the product. Relating it to the present study, the senses theory houses all the independent variables needed in this study. Therefore, this study on the relationship between the sensory attributes and consumer purchase decisions has all the independent variables originated from this theory and also anchored on it.

\subsection{Proposed conceptual model for the study}

\section{DATA AND METHODS}

The study adopted a cross-sectional survey research design. The target population of the study comprises the consumers of the selected malt brands in Southeastern Nigeria. The population size for this study is unknown, and the sampling frame does not exist because there is no record or database in the study

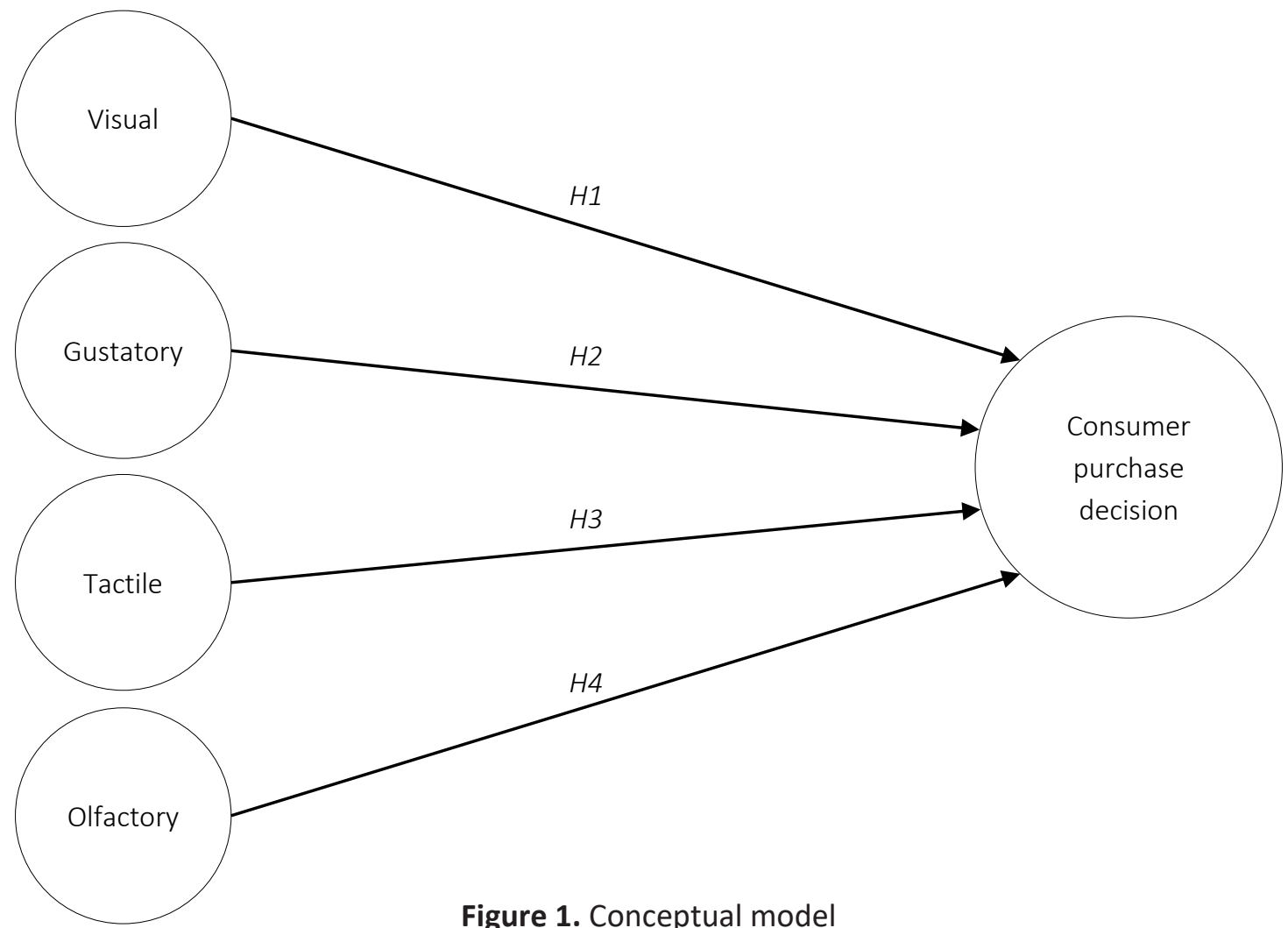

Figure 1. Conceptual model 
areas that revealed a specified number of malt customers. The sample size of 384 consumers of selected malt brands (Maltina, Malta Guinness, Amstel Malta, Dubic Malt, and Grand Malt) was determined using Topman formula to determine the sample size of the unknown population. However, respondents were drawn from Abia, Anambra, Ebonyi, Enugu, and Imo states in South-eastern Nigeria using the state capitals, namely Umuahia, Awka, Abakaliki, Enugu, and Owerri. The study adopted a non-probability sampling technique because of the absence of a sampling frame, which made the use of probability sampling technique (simple random, systematic, and stratified sampling methods) impossible to be used in this study.

Therefore, a convenience sampling technique, which is a non-probability sampling procedure, was adopted. Malt consumers aged 18 years and older found drinking the selected malt brands under investigation from the selected sales outlets in the geographical areas under study were surveyed. Because of consumers' dynamic and unpredictable nature, the implementation of the convenience sampling method was achieved by using only malt consumers who were present and also seen drinking or consuming the required malt brands under investigation in those chosen sales outlets segmented across the geographical areas under examination. Importantly, the use of the convenience sampling method was supported by Eboh (2009) that maintained that the researcher can use the sample units that are available at the time of data collection since the overriding principle is based on respondents' availability and researcher's convenience. Besides, the restriction on age became pivotal as persons below the age of 18 in Nigeria are legally considered as minors with limited capacity for independent decisions. The rationale for using only adult malt consumers was to elicit informed responses to the questions raised for the survey.

The source of data collection was the primary source facilitated using self-administered copies of the questionnaire as the survey instrument. The questionnaire items were extracted from the extant literature. The scales used in this study were adapted from previous studies and modified to suit the context of the present study. The measurement scales were adapted from the previous studies (Zia, 2017; Taiye, Dirisu, Ogunnaike, \& Onochie, 2015 for visual; Raj \& Shiny, 2017 for gustatory; Park \& Im, 2019 for tactile;
Chatterjee, 2017 for olfactory; and Njoroge, 2017 for consumer purchase decision). Also, face and content validity were checked for the instrument using three experts who enhanced its suitability in measuring what it was supposed to measure. The questionnaire items for each construct were checked for internal consistency. A pilot test was conducted using test-retest method because of modifications made to the measuring instrument. Besides, Cronbach's alpha average coefficient of 0.721 and average composite reliability value of 0.732 were obtained, which established the internal consistency of the study constructs, as shown in Table 1 . The average variance extracted (AVE) values ranging from 0.505 to 0.637 confirmed the convergent validity among the constructs based on the threshold by Hair, Hult, Ringle, and Sarsted (2017), as shown in Table 1.

Table 1. Reliability and validity of the instrument

Source: PLS-SEM algorithm output.

\begin{tabular}{l|c:c|c}
\hline \multicolumn{1}{c}{ Construct } & $\begin{array}{c}\text { Cronbach's } \\
\text { alpha }\end{array}$ & $\begin{array}{c}\text { Composite } \\
\text { reliability }\end{array}$ & $\begin{array}{c}\text { Average variance } \\
\text { extracted }\end{array}$ \\
\hline Visual & 0.700 & 0.710 & 0.544 \\
\hline Gustatory & 0.802 & 0.812 & 0.637 \\
\hline Tactile & 0.686 & 0.708 & 0.505 \\
\hline \begin{tabular}{l} 
Olfactory \\
\hdashline Consumer
\end{tabular} & 0.708 & 0.713 & 0.541 \\
$\begin{array}{l}\text { purchase } \\
\text { decision }\end{array}$ & 0.711 & 0.717 & 0.548 \\
\hline
\end{tabular}

\subsection{Administration of the instrument, method of data collection and analysis}

The questionnaire was administered to adult malt consumers of at least 18 years or older who were found drinking the malt brand under assessment in those selected bars, restaurants, and fast-food joints in commercial cities of Awka, Enugu, Abakaliki, Owerri, and Umuahia. Besides, copies of the questionnaire were distributed to the respondents by the researchers across the selected sales outlets used for the survey. Geographical coverage, even spread of the outlets, popularity of the sales outlets, presence of large market share of malt consumers were some of the criteria adopted. Details on how the instrument was allocated, distributed, retrieved, and used for analysis are contained in Appendix C. Furthermore, the time horizon for the field survey was cross-sectional, whereby the copies of the questionnaire were distributed to the respondents 
only once within the stipulated period. The data collection lasted for 82 days at different periods to minimize sampling bias and obtain a varied blend of respondents (Kok \& Fon, 2014). Data generated from the respondents were presented in frequency tables. Descriptive statistics analysis was used to describe the data generated from the respondents. The Partial Least Squares Structural Equation Modeling was used to test the hypotheses formulated for the study at $5 \%$ level of significance. This was facilitated using Smart PLS-SEM version 3. The decision rule for the acceptance or rejection of the hypotheses is to accept the alternative hypothesis if the $p$-value is less than 0.05; otherwise, reject.

\subsection{Respondent's profile}

The researcher distributed 384 copies of the questionnaire to the respondents, 356 copies $(92.7 \%$ response rate) were properly filled and validated for the data analysis, while 28 copies (7.3\%) were not used for the analysis. Based on the useable sample, $34 \%$ of the respondents were males, while $66 \%$ of the respondents were females, which revealed the dominance of females segment over males in the survey. The survey revealed that 83 representing $23.3 \%$ of the respondents belong to working day drinkers; 68 representing $19.1 .3 \%$ of the respondents belong to working night drinkers; 46 representing $12.9 \%$ of the respondents belong to weekend day drinkers; 42 representing $11.8 \%$ of the respondents belong to weekend night drinkers; 101 representing $28.4 \%$ of the respondents belong to anytime heavy drinkers; 14 representing $3.9 \%$ of the respondents belong to anytime casual drinkers, while 2 representing $0.6 \%$ of the respondents belong to occasional drinkers. With regards to marital status, $66.9 \%$ of the respondents are single; $31.5 \%$ of the respondents are married; $1.1 \%$ of the respondents are divorced, while $0.6 \%$ of the respondents are widowed.

Concerning the age of the respondents, $41.6 \%$ of the respondents are within the age range of 18-30 years; $31.7 \%$ of the respondents are within the age range of $31-40$ years; $18.5 \%$ of the respondents are within the age range of $41-50$ years, while $8.1 \%$ of the respondents are above 50 years. This finding implies that younger people (youths) patronize malt drinks more than older people. Moreover, the income distribution of malt consumers on an average monthly income, denominated in Nigerian Naira (N), indicates that $1.4 \%$ of the respondents earn an average monthly income below $\mathrm{N} 18,000 ; 16.9 \%$ of the respondents get an average monthly income range of $\mathrm{N} 18,000$ - $\$ 38,999 ; 23 \%$ of the respondents get an average monthly income range of $\$ 39,000-\$ 69,999 ; 28.7 \%$ of the respondents get on the average monthly income range of $\mathrm{N} 70,000$ - $\mathrm{N} 99,999$, while $30.1 \%$ of the respondents get on the average monthly income range of $\mathrm{N} 100,000$ and above. This implies that consumers can afford to buy any brand of malt.

\subsection{Descriptive statistics}

A cursory analysis of the descriptive statistics based on the respondents' mean responses, as shown in Table 2, revealed the degree of importance and the rank of each of the constructs and indicators used in measuring sensory purchasing motives. Based on field survey analysis, the malt brand gustatory attribute is the most important variable that enhances consumer purchase decisions as rated by the respondents, followed by brand olfactory attribute, brand visual attribute, and brand tactile attribute. Also, the highest indicator ranked by malt consumers is GUS2, which represents low sugar taste, while VIS4 that is the shape of a particular malt brand bottle/can/pack is the lowest appreciated indicator, as revealed by the descriptive statistics based on field survey findings. Pertinently, the field survey findings have significant implications for malt manufacturers and managers, especially when making brand management decisions. Specifically, the mean responses for color, size, appearance, shape, and design of malt range from 3.12 to 4.12, which indicate that malt consumers consider visual attributes of malt brands as very important while making purchase decisions.

Furthermore, the mean responses for good taste, low sugar taste, sweet taste, cream taste, and sucrose taste of malt range from 3.24 to 4.54 , showing that malt consumers value as extremely important gustatory properties of malt brands while making purchase decisions. The mean responses for malt brand feel, weight, chillness, glossiness, and smoothness range from 3.34 to 3.98 , which portray that malt consumers consider as very important, the tactile attributes of malt brands. Also, the mean responses for malt brand pleasant smell, flavor, aroma, fragrance, and pleasant odor range from 3.69 to 4.32 , showing that malt consumers 
value as very important, the olfactory properties of malt brands while purchasing malt. Consequently, the descriptive statistics, as shown in Table 2, implies that all the indicators and the study constructs have relevant and significant influence levels in providing solutions to the research questions or objectives of this research ranging from somewhat important to extremely important. This implies that, on average, consumer values and decides to purchase malt brands based on the sensory attributes.

Table 2. Descriptive statistics

Source: Field survey.

\begin{tabular}{|c|c|c|c|c|}
\hline Items & Description & Mean & $\begin{array}{l}\text { Std. } \\
\text { dev. }\end{array}$ & Rank \\
\hline VIS1 & $\begin{array}{l}\text { Malt brand color of bottle/can/ } \\
\text { pack }\end{array}$ & 3.86 & 1.149 & $9^{\text {th }}$ \\
\hline VIS2 & Malt brand bottle/can/pack size & 3.83 & 1.137 & $13^{\text {ths }}$ \\
\hline VIS3 & $\begin{array}{l}\text { Malt brand appearance of bottle/ } \\
\text { can/pack }\end{array}$ & 3.86 & 1.157 & $10^{\text {th }}$ \\
\hline VIS4 & $\begin{array}{l}\text { Shape of a preferred malt brand } \\
\text { bottle/can/pack }\end{array}$ & 3.12 & 1.189 & $20^{\text {th }}$ \\
\hline VIS5 & $\begin{array}{l}\text { Design of a favorite malt brand } \\
\text { bottle/can/pack }\end{array}$ & 4.12 & .877 & $4^{\text {th }}$ \\
\hline GUS1 & $\begin{array}{l}\text { Good taste of the preferred malt } \\
\text { brand }\end{array}$ & 4.40 & .786 & $2^{\text {nd }}$ \\
\hline GUS2 & $\begin{array}{l}\text { Low sugar taste of a particular malt } \\
\text { brand }\end{array}$ & 4.54 & .681 & $1^{\text {st }}$ \\
\hline GUS3 & $\begin{array}{l}\text { Sweet taste of a particular malt } \\
\text { brand }\end{array}$ & 3.24 & 1.420 & $19^{\text {th }}$ \\
\hline GUS4 & Malt brand creamy taste & 3.92 & .943 & $7^{\text {th }}$ \\
\hline GUS5 & $\begin{array}{l}\text { Sucrose taste of a preferred malt } \\
\text { brand }\end{array}$ & 4.08 & .925 & $5^{\text {th }}$ \\
\hline TAC1 & $\begin{array}{l}\text { Malt brand Feel/texture of bottle/ } \\
\text { can }\end{array}$ & 3.78 & 1.090 & $14^{\text {th }}$ \\
\hline TAC2 & $\begin{array}{l}\text { Malt brand weight of bottle/can/ } \\
\text { pack }\end{array}$ & 3.54 & 1.178 & $16^{\text {th }}$ \\
\hline TAC3 & $\begin{array}{l}\text { Chillness of a particular malt brand } \\
\text { bottle/can/pack }\end{array}$ & 3.98 & .980 & $6^{\text {th }}$ \\
\hline TAC4 & $\begin{array}{l}\text { Glossiness of a preferred malt } \\
\text { brand bottle/can }\end{array}$ & 3.34 & 1.229 & $18^{\text {th }}$ \\
\hline TAC5 & $\begin{array}{l}\text { Smoothness of a particular malt } \\
\text { brand bottle/can }\end{array}$ & 3.47 & 1.243 & $17^{\text {th }}$ \\
\hline OLF1 & Malt brand pleasant smell & 3.88 & 1.035 & $8^{\text {th }}$ \\
\hline OLF2 & Flavor of a preferred malt brand & 4.32 & .791 & $3^{\text {rd }}$ \\
\hline OLF3 & Malt brand aroma & 3.83 & 1.049 & $12^{\text {th }}$ \\
\hline OLF4 & Malt brand fragrance smell & 3.69 & 1.227 & $15^{\text {th }}$ \\
\hline OLF5 & $\begin{array}{l}\text { Pleasant odor of a favorite malt } \\
\text { brand }\end{array}$ & 3.85 & 1.085 & $11^{\text {th }}$ \\
\hline CPD1 & $\begin{array}{l}\text { Purchase decision because of malt } \\
\text { brand visual attribute }\end{array}$ & 3.59 & 1.240 & $3^{\text {rd }}$ \\
\hline CPD2 & $\begin{array}{l}\text { Purchase decision due to malt } \\
\text { brand gustatory attribute }\end{array}$ & 3.87 & 1.122 & $1^{\text {st }}$ \\
\hline CPD3 & $\begin{array}{l}\text { Purchase decision because of malt } \\
\text { brand tactile attribute }\end{array}$ & 3.50 & 1.377 & $4^{\text {th }}$ \\
\hline CPD4 & $\begin{array}{l}\text { Purchase decision due to malt } \\
\text { brand olfactory attribute }\end{array}$ & 3.70 & 1.179 & $2^{\text {nd }}$ \\
\hline
\end{tabular}

\section{RESULTS}

\subsection{Assessment of the structural model}

The significance and relevance of the structural model were evaluated based on the values of the path coefficients, statistical $t$-values, and the $p$-values. The hypotheses were tested and assessed through the bootstrapping procedure in Smart PLS 3.0 (Ramayah, 2015). The study adopted the standardized root mean square residual (SRMS), the root mean square residual covariance ( $\mathrm{RMS}_{\text {the- }}$ ta , and normed fit index (NFI) as the measures for the assessment of PLS-SEM goodness of fit. The three models fit measures results show that the SRMR value is $0.041, \mathrm{RMS}_{\text {theta }}$ value is 0.0255 , and the NFI value is 0.912 , which portrayed a well-fitting model. This implies that the model is well fitted for the data and that the threshold for acceptance of the fitness of the model used in the study was therefore met. The coefficient of determination $\left(R^{2}\right)$ measures the total variance explained in the endogenous construct as a result of changes in the model's exogenous variables. The model explains the significant positive variance of 0.775 (77.5\%) for consumer purchase decisions. The $R^{2}$ value generated showed the substantial power of the exogenous constructs to explain the endogenous construct, which is clearly above the threshold given that the $R^{2}$ values of $0.75,0.50$, and 0.25 represent substantial, moderate, and weak, respectively (Hair, Hult, Ringle, \& Sarstedt, 2017). Accordingly, Table 3 depicts the PLS-SEM results for the test of hypothesized relationships postulated.

Considering that the path coefficient should be equal to or greater than 0.20 to demonstrate its significance, the $t$-value should be $\geq 1.96$, while the $p$-value should be $\leq 0.05$ to be significant (Wong, 2013). An examination of the path coefficients, $t$-values and $p$-values of the structural model in Table 3 show that malt brand visual attribute had a positive significant relationship with consumer purchase decision $(\beta=0.238, t=3.701, p<0.05)$. Also, malt brand gustatory attribute had a positive significant relationship with consumer purchase decision $(\beta=0.426, t=10.118, p<0.05)$. Similarly, tactile attribute of malt brand had a significant positive relationship with consumer purchase decision $(\beta=0.219, t=2.799, p<0.05)$. Finally, malt 


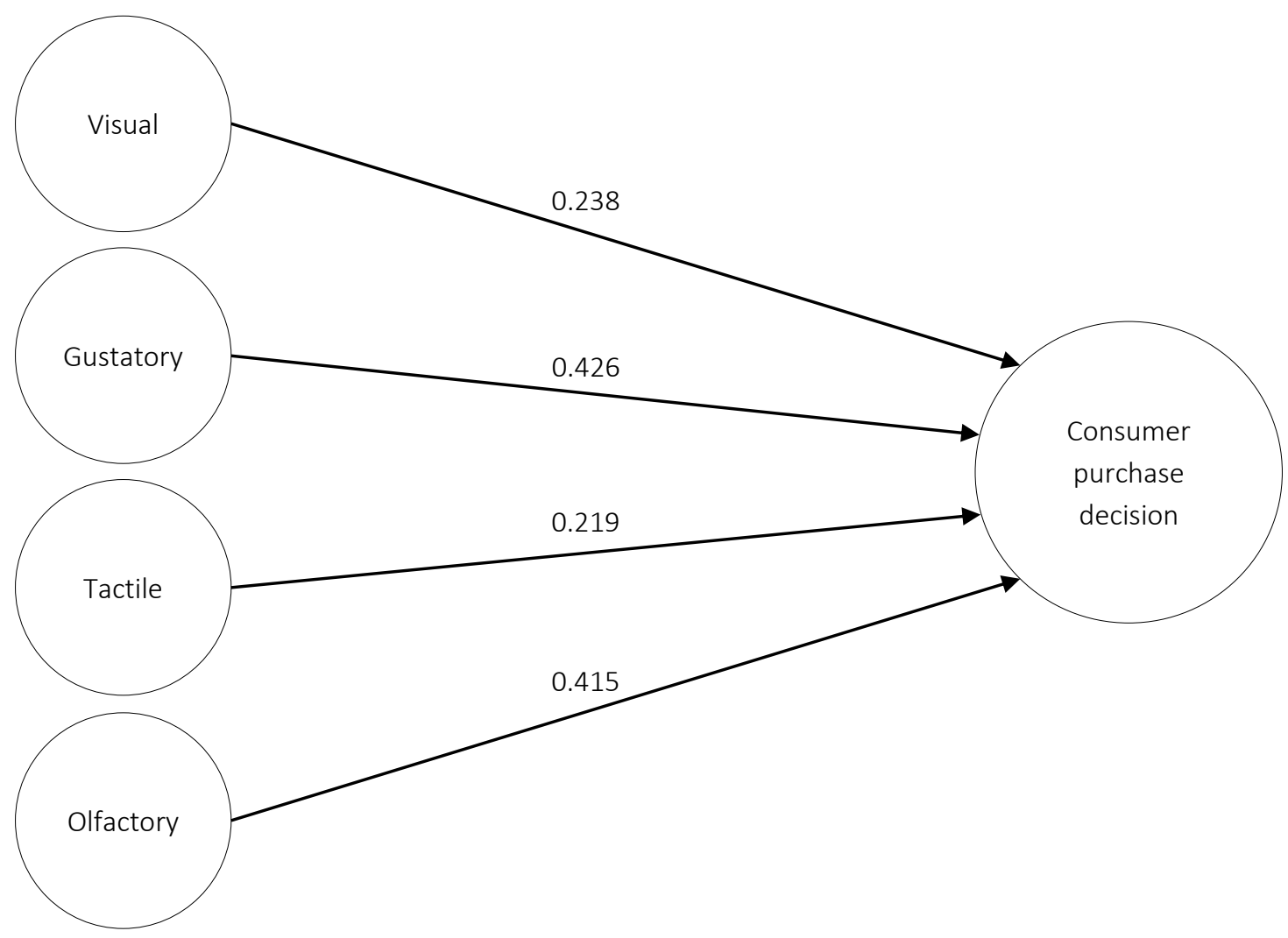

Note: $6 \geq 0.20^{*} ; t \geq 1.96^{*}$ and ${ }^{*} p \leq 0.05$ (to be significant).

Figure 2. Structural model results

Table 3. Bootstrapping results of the structural model and path analysis

Source: SEM-PLS output.

\begin{tabular}{|c|c|c|c|c|c|}
\hline Hypotheses & Hypotheses paths & Path coefficients & $t$-values & $p$-values & Decisions \\
\hline $\mathrm{H} 1$ & $\mathrm{VIS} \rightarrow \mathrm{CPD}$ & 0.238 & 3.701 & 0.000 & Supported \\
\hline $\mathrm{H} 2$ & GUS $\rightarrow$ CPD & 0.426 & 10.118 & 0.000 & Supported \\
\hline $\mathrm{H} 3$ & $\mathrm{TAC} \rightarrow \mathrm{CPD}$ & 0.219 & 2.799 & 0.005 & Supported \\
\hline $\mathrm{H} 4$ & $\mathrm{OLF} \rightarrow \mathrm{CPD}$ & 0.415 & 9.586 & 0.000 & Supported \\
\hline
\end{tabular}

Note: VIS: visual; GUS: gustatory; TAC: tactile; OLF: olfactory; CPD: consumer purchase decision. Path is significant at $5 \%$ level of significance; if the $t$-value is $\geq 1.96$, or $p$-value $\leq 0.05$.

brand olfactory attribute had a positive significant relationship with consumer purchase decision $(\beta$ $=0.415, t=9.586, p<0.05)$. Accordingly, all the hypotheses $(H 1, H 2, H 3$, and $H 4)$ were supported.

\section{DISCUSSION}

The results presented in Table 3 indicated that malt brand visual attribute had a significant pos- itive relationship with consumer purchase decisions. The findings of the study are in accordance with the findings within the extant literature (Krishna, 2012; Zia, 2017) that found that visual attributes of a product or brand have a significant positive relationship with consumer purchase decisions. The research findings corroborate with the a priori expectations of the conceptual model used for this study, which states that the brand visual attribute of malt has 
a significant positive relationship with consumer purchase decisions. The statistical significance of this construct is related to high customer expectations regarding product attributes that will appeal to their senses, value proposition for the color, size, shape, attractiveness, and the design of the bottles/cans/packs of malt brand while making purchase decisions. Besides, our findings confirm the findings of Taiye et al. (2015). However, this is contrary to the findings of Hassan et al (2012) who found that visual attributes do not significantly influence consumer purchase decisions. Moreover, and in line with the findings, there is a significant positive relationship between visual attribute and consumer purchase decisions. Gere, Danner, Antoni, Kovacs, Durrschmid, and Sipos (2016) found a significant relationship between consumer choice of brands of product and gazing behavior. This supports the findings of Steinhauser et al. (2019) who found that consumer purchase decision was significantly influenced by consumer visual attention (gazing behavior). Both findings of Gere et al. (2016) and Steinhauser et al. (2019) posit that the more the consumer looks fixedly on a product, the more he or she is ready to make a purchase. Consequent to this, Halabi and Hands (2018) affirmed that consumer aesthetic evaluation and purchase of a product are significantly affected by the visual aesthetic appearance.

Gustatory attribute of malt brand has a positive significant relationship with consumer purchase decision. This finding is consistent with the previous studies (Ray \& Shiny, 2017; Schiano, Harwood, \& Drake, 2017) who found a significant and positive relationship between product gustatory attribute and consumer purchase decisions. The findings of this research tend to align with Muntaha (2016) who reported that the better the taste of malt, the more likely that the consumers will be satisfied with the brand and tend to purchase it more. The finding of this study is consistent with the findings of Altamore, Ingrassia, Chironi, Columba, Sortino, Vukadin, and Bacarella (2018) who reinforced that taste is always an essential driver of consumer purchase of a product. Besides, the finding of this study supports the findings of Raj and Shiny (2017) contrary to the findings of Carvalho, Qian, Van Ee, and Spence (2016) that showed that gustatory attribute does not have a significant influence on consumer purchase decisions.

Besides, tactile attribute of malt brand had a significant positive relationship with consumer purchase decisions. This finding supports previous findings within the extant literature (Park \& Im, 2019; Heiltjes, 2014; Balaji et al., 2011), which found that tactile attributes positively relate to consumer purchase decisions. Also, the finding of this work is in tandem with Goel and Sathwara (2016) who found that the more opportunities for physical touch-points available to customers, the more likely they will decide to make purchase decisions. Besides, the finding of this research is in accordance with the findings of Streicher and Etes (2016). Nevertheless, this is contrary to the findings of Muntaha (2016) that revealed that tactile attribute has no significant influence on consumer purchase decisions.

Furthermore, the olfactory attribute of malt brands has a significant positive relationship with consumer purchase decisions. This study's finding is in tune with the findings of Balla and Deari (2015) who found that olfaction significantly influences product purchase. In line with this, Chatterjee (2017) confirmed in his study that the influence of fragrance on consumer choice and purchase decision was significant. Similarly, Pezoldt et al. (2014) found that ambient scent significantly influences consumer purchase decisions. Moreover, the finding of this research is in agreement with the findings of Elangovan and Padma (2017) who found that olfaction positively influences consumer purchase decisions. This is because it places the consumer in a state of emotional equilibrium. This study's finding is also in line with the findings of Anggie and Haryanto (2011) who found that olfaction is a very important factor in product evaluation and consumer purchase decisions. Furthermore, the finding of this study is in accordance with the finding of Moore (2014) and opposes Gueguen and Petr (2006) findings that revealed an insignificant relationship between product olfaction and consumer purchase decision. It means that olfaction is indispensable to consumer purchase decisions as supported by Goncalves, Srebernich, Vercelino, and Zampieri (2013). 


\section{CONCLUSION}

This study provides a contemporary understanding that malt drinks' multisensory attributes are significantly and positively related to consumer purchase decisions in Nigeria, which have relevant practical, theoretical, and managerial implications to the malt manufacturers and brand managers. Malt manufacturers and managers are expected to develop a strong bond between their products and their customers based on this research's findings. The study predicting variables are important and significant drivers of consumer purchase decisions. Gustatory attributes of malt play the most important role in predicting and influencing consumer purchase decisions of malt drinks in Nigeria. Convincingly, malt brand visual, tactile, and olfactory attributes also play a major role in propelling and facilitating consumer purchase decisions.

The study has also contributed to the body of existing knowledge by conceptually providing a comprehensive explanation of multisensory product attributes and consumer purchase decisions. This study has theoretically contributed to the body of existing theories in the field of multisensory marketing. This study's findings have contributed to identifying the nature and extent of the relationship between multisensory attributes of malt drinks and consumer purchase decisions. The introduction of mediating and moderating variables has also helped in advancing the already existing multisensory and consumer behavior theories and theoretical models. In similar terms, the findings of this study will be of great significance to malt manufacturers, brand managers, and other stakeholders in the industry. They will always integrate the multisensory aspect of their brands in communicating with their various stakeholders. It will also serve as an information repository threshold to the malt manufacturers, brand managers, and marketers, and other stakeholders in food and beverage companies for strategic policy formulations and implementations.

Further, this research has exhibited a strong analytical prowess in its methodology that has contributed significantly to the extant literature through the application of Partial Least Squares Structural Equation Modeling technique; a second-generation multivariate statistical technique developed to simultaneously estimate the relationships between the exogenous and endogenous constructs or complex relationships among constructs. This research has also supplied empirical evidence that there are significant and quantifiable relationships between the predicting variables and consumer purchase decisions of malt brands, as reflected in the findings of this study.

Suggestively, because the present study concentrated on the South-Eastern part of Nigeria, there is a need to expand the scope in future research to cover other geographical zones in Nigeria. The need to also investigate sensory purchasing motives for beer brands as a good number of Nigerian youths and even adults (male and female) do drink beer brands. Future studies may use a longitudinal type of survey design and procedure since the present study adopted a cross-sectional method. Besides, there is a need for experimental or causal research design in a future study to compare its results with the findings of this study.

\section{ACKNOWLEDGMENTS}

In the course of this study, a few researchers assisted and contributed immensely in developing the methodology for the study. They include: Prof. Donatus Chigbo Ngige, Dr. Ezeh Precious, Dr. Osegbue Francis Ifeanyi, Dr. Ofor Theresa Nkechi, Prof. Mary Margret N. Okeke, Mrs Vivian C. Anetoh and Dr. Egbeh Placid C. Thank you very much and God bless you all. Also, we thank our respondents who supplied us with the needed data that made this study a reality.

\section{AUTHOR CONTRIBUTIONS}

Conceptualization: John Anetoh, Victor Okolo, Chinedum Obikeze, Ifeanyichukwu Oranusi.

Data curation: John Anetoh, Victor Okolo, Zita Mmamel, Chinedum Obikeze, Ifeanyichukwu Oranusi. Formal analysis: John Anetoh, Victor Okolo, Zita Mmamel, Chinedum Obikeze, Ifeanyichukwu Oranusi. 
Funding acquisition: Victor Okolo, Chinedum Obikeze, Ifeanyichukwu Oranusi.

Investigation: Victor Okolo, John Anetoh, Zita Mmamel, Chinedum Obikeze, Ifeanyichukwu Oranusi. Methodology: John Anetoh, Victor Okolo, Zita Mmamel, Chinedum Obikeze, Ifeanyichukwu Oranusi. Project administration: John Anetoh, Victor Okolo, Zita Mmamel.

Resources: Victor Okolo, John Anetoh, Zita Mmamel, Chinedum Obikeze, Ifeanyichukwu Oranusi. Software: John Anetoh, Victor Okolo, Chinedum Obikeze, Ifeanyichukwu Oranusi.

Supervision: John Anetoh, Victor Okolo, Zita Mmamel.

Validation: Victor Okolo, John Anetoh, Zita Mmamel, Chinedum Obikeze, Ifeanyichukwu Oranusi. Visualization: Victor Okolo, John Anetoh.

Writing - original draft: John Anetoh, Victor Okolo, Zita Mmamel, Chinedum Obikeze.

Writing - review \& editing: John Anetoh, Victor Okolo, Zita Mmamel.

\section{REFERENCES}

1. Abari, N., \& Safitri, I. (2018). The influence of product price on consumers' purchasing decisions. Review of Integrative Business and Economics Research, 7(2), 328-337. Retrieved from https:// www.researchgate.net/publication/339796716_The_Influence_ of_Product_Price_on_Consumers'_Purchasing_Decisions

2. Altamore, L., Ingrassia, M., Chironi, S., Columba, P., Sortino, G., Vukadin, A., \& Bacarella, S. (2018). Pasta experience: eating with the five senses - a pilot study. AIMS Agriculture and Food, 3(4), 493-520. https://doi.org/10.3934/ agrfood.2018.4.493

3. Amankwah, M. O. (2017). Determinants of purchase decisions of consumers of the products of nestle Ghana limited (Ph.D. Thesis). Kwame Nkrumah University of Science and Technology, School of Business Ghana.

4. Anggie, C., \& Haryanto, J. O. (2011). Analysis of the effect of olfactory, approach behavior and experiental marketing toward purchase intention. Gadjah Mada International Journal of Business, 13(1), 85-101. Retrieved from https://jurnal.ugm.ac.id/gamaijb/ article/view/5496

5. Balaji, M. S., Srividya, R., \& Subhash, J. (2011). Role of tactile and visual inputs in product evaluation: a multisensory perspective in India. Asia Pacific Journal of Marketing and Logistics, 23(4), 513-530. Retrieved from https://www.semanticscholar.org/ paper/Role-of-tactile-and-visualinputs-in-product-a-Balaji-Raghav an/0f0986ce70b3a7df63c66a272fd 60c5a4f53ca07

6. Balla, E., \& Deari, H. (2015). How do product's attributes affect consumer behavior: an empirical evidence of brand choice. International Journal of Economics, Commerce and Management, 3(8), 38-46. Retrieved from http:// ijecm.co.uk/wp-content/uploads/2015/08/384.pdf

7. Blackwell, R. D., Miniard, P. W. \& Engel, J. F. (2005). Consumer behavior (10th ed.). South Western College, USA, California.

8. Bulsara, H. P., \& Trivedi, K. G. (2016). An exploratory study of factors related to consumer behaviour towards purchase of fruits and vegetables from different retail formats. Journal of Research in Marketing, 6(1), 397406. https://doi.org/10.17722/jorm. v6i1.131

9. Cano, M. B., Perry, P., Ashman, A., \& Waite, K. (2017). The influence of image interactivity upon user engagement when using mobile touch screens. Computers in Human Behavior, 77, 406412. https://doi.org/10.1016/j. chb.2017.03.042

10. Carvalho, F. R., Qian, W., Van Ee, R., \& Spence, C. (2016). The influence of soundscape on the perception and evaluation of beers in Spain. Journal of Food Quality \& Preference, 52(1),
32-41. https://doi.org/10.1016/j.

foodqual.2016.03.009

11. Chatterjee, S. (2017). Brand loyalty on the basis of olfactory techniques using discriminant analysis: a case of cafe coffee day store in Kolkata, India. Academy of Marketing Studies Journal, 21(1), 1-6. Retrieved from https://www. abacademies.org/articles/brandloyalty-on-the-basis-of-olfactorytechniques-using-discriminantanalysis-a-case-of-cafe-coffee-daystore-in-kolkata-india-6635.html

12. Cortina-Mercado, M. (2017). Effect of packaging design in the purchase decision process: a comparison of generations. Global Journal of Business Research, 11(2), 11-26. Retrieved from https:// www.theibfr.com/download/ gjbr/2017_gjbr/gjbr_v11n2_2017/ GJBR-V11N2-2017-2.pdf

13. Dubenova, E., \& Koch, S. (2019). Product attributes that facilitate disruption survival in declining markets (Master's Thesis). Lund University.

14. Eboh, E. C. (2009). Social and Economic Research: Principles and Methods. Enugu: African Institute for Applied Economics.

15. Elangovan, N., \& Padma, C. (2017). Impact of Multi Sensory Marketing on Consumer Behavior in Restaurant. International Journal of Business and Management Invention, 6(2), 1-9. Retrieved from https://www.ijbmi. org/papers/Vol(6)2/version-4/ A0602040109.pdf 
16. Gallace, A., \& Spence, C. (2014). In touch with the future: the sense of touch from cognitive neuroscience to virtual reality. Oxford, UK: Oxford University Press.

17. Gere, A., Danner, L., Antoni, N. D., Kovacs, S., Durrschmid, K., \& Sipos, L. (2016). Visual attention accompanying food decision process: an alternative approach to choose the best models. Food Quality and Preference, 51, 1-7. https://doi.org/10.1016/j. foodqual.2016.01.009

18. Goel, R., \& Sathwara, H. (2016). 'Will you buy if others touch it'? A study on evaluation of products touched by others during shopping in Noida region. The International Journal of Business and Management, 4(3), 385-392. Retrieved from www.theijbm.com

19. Goncalves, G. M. S., Srebernich, S. M., Vercelino, B. G., \& Zampieri, B. L. (2013). Influence of the presence and type of fragrance on the sensory perception of cosmetic formulations. Brazilian Archives Biology and Technology, 56(2), 203-212. Retrieved from https://www.scielo.br/scielo.php?script=sci_arttext\&pid $=$ S1516-89132013000200005

20. Grohmann, B., Spangenberg, E. R., \& Sprott, D. E. (2007). The influence of tactile input on the evaluation of retail product offerings. Journal of Retailing, 83(2), 237-245. https://doi. org/10.1016/j.jretai.2006.09.001

21. Gueguen, N., \& Petr, C. (2006). Odors and consumer behavior in a restaurant. International Journal of Hospitality Management, 25(1), 335-339. Retrieved from https:// www.researchgate.net/publication/228435964_Odors_and_consumer_behavior_in_a_restaurant

22. Hair, J. F., Hult, G. T. M., Ringle, C. M., \& Sarstedt, M. (2017). A primer on partial least squares structural equation modeling (PLSSEM) (2nd ed.) (390 p.). Thousand Oaks: Sage Publications.

23. Halabi, K. N. M., \& Hands, D. (2018). Identifying and aligning product attributes' with latent consumer purchase motivations. Asian Journal of Social Sciences and Management Studies, 5(1), 16-22. https://doi.org/10.20448/journal.500.2018.51.16.22

24. Hanaysha, J. R. (2017). An examination of the factors affecting consumer's purchase decision in the Malaysian retail market. PSU Research Review, 2(1) 7-23. https:// doi.org/10.1108/PRR-08-20170034

25. Heiltjes, S. (2014). Touching Brands: the effects of multisensory packaging design on brand and product perception and evaluation. University of Twente.

26. Imiru, G. A. (2017). The effect of packaging attributes on consumer buying decision behavior in major commercial cities in Ethiopia. International Journal of Marketing Studies, 9(6), 43-54. https://doi. org/10.5539/ijms.v9n6p43

27. Jenyo, G. K., \& Soyoye, K. M. (2015). Online marketing and consumer purchase behaviour: a study of Nigerian firms. British Journal of Marketing Studies, 3(7), 1-14. Retrieved from https://silo. tips/download/online-marketingand-consumer-purchase-behaviour-a-study-of-nigerian-firms

28. Kampfer, K., Leischnig, A., Ivens, B. S., \& Spence, C. (2017). Touch-flavor transference: assessing the effect of packaging weight on gustatory evaluations, desire for food and beverages, and willingness to pay. PLoS ONE, 12(10), 1-17. https://doi. org/10.1371/journal.pone.0186121

29. Kathuria, L. M., \& Gill, P. (2013). Purchase of branded commodity food products: empirical evidence from India. British Food Journal, 115(9), 1255-1280. https://doi. org/10.1108/BFJ-08-2011-0209

30. Khuong, M. N., \& Duyen, H. T. N. (2016). Personal factors affecting consumer purchase decision towards men skin care products: a study in Ho Chi Minh City, Vietnam. International Journal of Trade, Economics and Finance, 7(2), 44-49. Retrieved from https://www.researchgate.net/ publication/318964561_Person-
al_Factors_Affecting_Consumer_ Purchase_Decision_towards_Men_ Skin_Care_Products_-_A_Study_ in_Ho_Chi_Minh_City_Vietnam

31. Kok, W. K., \& Fon, S. O. (2014). Shopper perception and loyalty: a stochastic approach to modeling shopping mall behaviour. International Journal of Retail Distribution Management, 42(7), 626-642. https://doi.org/10.1108/ IJRDM-11-2012-0100

32. Kotler, P. (2014). Marketing Management. New Jersey: Pearson Education Inc; Upper Saddle River, New Jersey, USA.

33. Kotler, P., Armstrong, G., \& Opresnik, M. O. (2018). Principles of marketing (17th ed.). UK: Pearson Education Ltd.

34. Kraus, A. (2015). Factors influencing the decisions to buy and consume functional food. British Food Journal, 17(6), 16221636. https://doi.org/10.1108/BFJ08-2014-0301

35. Krishna, A. (2012). An integrative review of sensory marketing: engaging the senses to affect perception, judgment and behavior. Journal of Consumer Psychology, 22(1), 332-351. https://doi. org/10.1016/j.jcps.2011.08.003

36. Krishna, A., Cian, L., \& Aydinoglu, N. Z. (2017). Sensory aspects of package design. Journal of Retailing, 93(1), 43-54. https://doi. org/10.1016/j.jretai.2016.12.002

37. Latasha, K., Tooraiven, P., \& Randhir, R. (2016). Analyzing the impact of sensory marketing on consumers: A case of Kentucky fried chicken in Mauritius. Proceedings of International conference on Tourism, Hospitality and Marketing (ICI6 Mauritius Conference), Ebene-Mauritius, 21-23(January). Retrieved from https://www.researchgate.net/ publication/304171131_Analyzing_the_Impact_of_Sensory_Marketing_on_Consumers_A_Case_ Study_of_KFC

38. Malik, V. S., Schulze, M. B., \& $\mathrm{Hu}, \mathrm{F}$. B. (2016). Intake of sugar-sweetened beverages and weight gain: a systematic 
review. American Journal of Clinic Nutrition, 84(2), 274-288. https:// doi.org/10.1093/ajen/84.1.274

39. Meng, H. (2016). The effects of scent on consumer behaviour (Ph.D. Thesis). USA: Kent State University.

40. Mertens, S., Hahnel, U. J. J., \& Brosch, T. (2020). This way please: Uncovering the directional effects of attribute translations on decision making. Judgment and decision making, 15(1), 25-46. Retrieved from https://www.researchgate.net/ publication/338954924_This_ way_please_Uncovering_the_ directional_effects_of_attribute_ translations_on_decision_making

41. Mesquita, A. S., \& Marques, T. (2013). The influence of olfactory marketing on clients' loyalty (Master's Thesis). ISCTE Business School.

42. Moore, D. J. (2014). Is anticipation delicious? Visceral factors as mediators of the effect of olfactory cues on purchase intentions. Journal of Business Research, 67(9), 2045-2051. https://doi. org/10.1016/j.jbusres.2013.10.005

43. Muntaha, A. (2016). The effect of multisensory branding on purchase intention at coffee shops in South Africa (A Dissertation in Marketing). University of the Witwatersrand, Johannesburg in South Africa.

44. Njoroge, J. (2017). Factors that influence consumer purchasing behavior in the consumption of cocacola novida malt soft drinks in Nairobi, Kenya (Master's Dissertation in Business Administration). Chandaria School of Business.

45. Oghojafor, A. B., Adeosun, L. P. K., \& Ganiyu, R. A. (2013). The influence of product attributes on consumer purchase decision in the Nigerian food and beverages industry: A study of Lagos Metropolis. American Journal of Business and Management, 1(4), 23-36. https://doi. org/10.11634/216796061706211

46. Okolo, V. O. (2017). Evaluation of the effects of marketing strategies on consumer patronage of restaurants in Enugu (a study of Mr. Bigg's). European Journal of Social Science, 55(3), 297-320. Retrieved from https://www.europeanjournalofsocialsciences.com/ issues/PDF/EJSS_55_3_05.pdf

47. Onyango, G., Luvitaa, S. K., Unbehend, G., \& Haase, N. (2020). Nutrient composition, sensory attributes and starch digestibility of cassava porridge modified with hydrothermally-treated finger millet. Journal of Agriculture and Food Research, 2(1), 1-7. https:// doi.org/10.1016/j.jafr.2020.100021

48. Ozcan, E., Cupchik, G. C., \& Schifferstein, H. N. J. (2017). Auditory and visual contributions to affective product quality. International Journal of Design, 11(1), 35-50. Retrieved from http://www.ijdesign.org/index. php/IJDesign/article/view/2257

49. Parimala, H. (2014). Multi-sensory experience: five senses theory. India: Pass brains.

50. Park, J., \& Im, Y. (2019). Effects on the tactile affections of touch behavior and product material. Ergonomics International Journal, 3(2), 1-6. Retrieved from https:// www.researchgate.net/publication/336549851_Effects_on_the_ Tactile_Affections_of_Touch_Behavior_and_Product_Material

51. Parnamets, P., Johansson, R., Gidlöf, K., \& Wallin, A. (2016). How information availability interacts with visual attention during judgment and decision tasks. Journal of Behavioral Decision Making, 29(1), 218-231. https://doi.org/10.1002/bdm.1902

52. Pezoldt, K., Michaelis, A., Roschk, H., \& Geigenmueller, A. (2014). The differential effects of extrinsic and intrinsic cue-utilization in hedonic product consumption: an empirical investigation. Journal of Business and Economics, 5(8), 1282-1293. Retrieved from http:// www.academicstar.us/UploadFile/ Picture/2015-1/201511611739562. pdf

53. Pramudya, R. C., \& Seo, H. S. (2019). Hand-feel touch cues and their influences on consumer perception and behavior with respect to food products: A review.
Foods, 8(259), 1-31. https://doi. org/10.3390/foods8070259

54. Raj, P. A., \& Shiny, S. (2017). A study of consumer preference towards malted drinks in Kanyakumari. International Journal of Research-Granthalayah, 5(4), 52-62. Retrieved from http:// granthaalayah.com/Articles/ Vol5Iss4/08_IJRG17_SE04_08.pdf

55. Ramayah, T. (2015). SmartPLS 3.0. School of Management Universiti Sains Malaysia.

56. Redondo, N., Gomez-Martinez, S., \& Marcos, A. (2014). Sensory attributes of soft drinks and their influence on consumers' preferences. Food and Function, 5, 1686-1694.

57. Rodrigues, C., Hulten, B., \& Brito, C. (2011). Sensorial brand strategies for value co-creation. Innovative Marketing, 7(2), 39-47. Retrieved from https:// businessperspectives.org/images/pdf/applications/publishing/ templates/article/assets/3993/ im_en_2011_02_Hulten.pdf

58. Saariluomaand, P., \& Jokinen, J. P. (2014). Emotional dimensions of user experience: a user psychological analysis. International Journal of HumanComputer Interaction, 30(4), 303-320. Retrieved from https:// www.researchgate.net/publication/261854098_Emotional_Dimensions_of_User_Experience_A_ User_Psychological_Analysis

59. Samuelson, C. L., \& Fontainini, A. (2017). Processing of intraoral olfactory and gustatory signals in the gustatory cortex of awake rats. The Journal of Neuroscience, 37(2), 244-257. Retrieved from https://www.jneurosci.org/content $/ 37 / 2 / 244$

60. Schiano, A. N., Harwood, W. S., \& Drake, M. A. (2017). A 100year review: sensory analysis of milk. Journal of Dairy Science, 100, 9966-9986. https://doi. org/10.3168/jds.2017-13031

61. Schnettler, B., Miranda, H., Lobos, G., Sepulveda, J., Orellana, L., Mora, M., \& Grunert, K. G. (2015). Willingness to purchase functional foods according to their benefits. 
British Food Journal, 117(5), 1453-1473. Retrieved from http:// repositorio.uchile.cl/bitstream/ handle/2250/132553/Willingnessto-purchase-functional-foodsaccording-to-their-benefits. pdf? sequence $=1$

62. Hassan, S. H., Leng, L. W., \& Peng W. W. P. (2012). The influence of food product packaging attributes in purchase decisions: A study among consumers in Penang, Malaysia. Journal of Agribusiness Marketing, 5(1), 14-28. Retrieved from https://www.researchgate. net/publication/267042545 THE_INFLUENCE_OF FOOD_PRODUCT_PACKAGING_ATTRIBUTES_IN_PURCHASE_DECISION_A_STUDY_ AMONG_CONSUMERS_IN_ PENANG_MALAYSIA

63. Spangenberg, E. R., Grohmann, B., \& Sprott, D. E. (2005). It's beginning to smell (and sound) a lot like christmas: the interactive effects of ambient scent and music in a retail setting. Journal of Business Research, 58(11), 1583 1589. https://doi.org/10.1016/j. jbusres.2004.09.005

64. Spence, C. (2015). Leading the consumer by the nose: on the commercialization of olfactory design for the food and beverage sector. Flavour, 4(31), 1-15. Retrieved from https://flavourjournal.biomedcentral.com/articles/10.1186/s13411-015-0041-1

65. Steinhauser, J., Janssen, M., \& Hamm, U. (2019). Who buys products with nutrition and health claims? a purchase simulation with eye tracking on the influence of consumers' nutrition knowledge and health motivation. Nutrients, 11(2199), 1-20. Retrieved from https://www. mdpi.com/2072-6643/11/9/2199

66. Streicher, M. C., \& Estes, Z. (2015). Touch and go: merely grasping a product facilitates brand perception and choice. Applied Cognitive Psychology, 29(3), 350359. https://doi.org/10.1002/ acp.3109

67. Taiye, T. B., Dirisu, J. F., Ogunnaike, O. O., \& Onochie, M. P. (2015). Empirical study of packaging and its effect on consumer purchase decision in a food and beverages firm in Nigeria. European Journal of Business and Social Sciences, 3(11), 44-53. Retrieved from www.ejbss. com/recent.aspx./ISSN:2235-767X

68. Thompson, L., Gerad, P. D., \& Drake, M. (2010). Chocolate milk and the Hispanic consumer. Journal of Food Science, 72(1), 666-675. https://doi.org/10.1111/ j.1750-3841.2007.00559.x

69. Torquati, B., Tempesta, T., Vecchiato, D., \& Venanzi, S. (2018). Tasty or sustainable? the effect of product sensory experience on a sustainable new food product: an application of discrete choice experiments on Chianina tinned beef. Sustainability, 10(2795), 1-24. Retrieved from https://ideas. repec.org/a/gam/jsusta/v10y2018i8p2795-d162374.html

70. Van Wymelbeke, V., BeridotTherond, M. E., de La Gueronniere, V., \& Fantino, M. (2014). Influence of repeated consumption of beverages containing sucrose or intense sweeteners on food intake. Europe Journal of Clinic Nutrition, 58(1), 154-161. https://doi.org/10.1038/ sj.ejcn. 1601762

71. Vijay, V., Thoppan, J. J., Nathan, R. J., \& Fekete, F. M. (2019). Factors influencing consumer behavior and prospective purchase decisions in a dynamic pricing environment: an exploratory factor analysis approach. Social Science, 7(153), 1-14. Retrieved from https://www.researchgate. net/publication/327500194_Factors_Influencing_Consumer_Behavior_and_Prospective_Purchase_Decisions_in_a_Dynamic_ Pricing_Environment-An_Exploratory_Factor_Analysis_Approach

72. Wang, Y., \& Wu, J. (2017). Retail in-store design and sensory cues (Master's Thesis). Jonkoping University.

73. Wei, S., Singgih, S., Woods, E. J., \& Adar, D. (2013). How important is appearance? Consumer preferences for mandarins in Indonesia. International Journal of Consumer Studies, 27(1), 406-411. https://doi.org/10.1046/j.14706431.2003.00332.x

74. Wong, K. K. (2013). Partial Least Squares Structural Equation Modeling (PLS-SEM) Techniques Using SmartPLS. Marketing Bulletin, 24(1), 1-32.

75. Wurz, D. A., Allebrandt, R., Bem, B. P. D., Bonin, B., Reinehr, J., Canossa, A. T. C., Rufato, L., \& Kretzschmar, A. A. (2017). Women have better olfactory perception for wine aromas. BIO Web of Conferences, 9, 04005. https://doi. org/10.1051/bioconf/20170904005

76. Zhang, K., Chen, Y., Guo, Y., Liu, S., Su, N., Guan, T., \& Zhu, S. (2016). Research of bamboo qualitative material tactile characteristics. Wood Research, 61(6), 1017-1032. Retrieved from https://www.researchgate.net/ publication/312550361_Research_ of_bamboo_qualitative_material_tactile_characteristics

77. Zia, M. (2017). Impact of product attributes on purchase decision: a study of processed food consumer in India. Proceedings of the Multidisciplinary Academic Conference Held at Prague, Czech Republic, 10(1), 1-11. Retrieved from https://www.researchgate. net/publication/319502479_Impact_of_Product_Attributes_on_ Purchase_Decision_A_Study_of_ Processed_Food_Consumer_in_ India 


\section{APPENDIX A}

\section{b. The consumer purchase decision theory}

This theory by Blackwell, Miniard, and Engel (2005) stated that a consumer undergoes a seven-point pre-purchase, purchase, and post-purchase decision stages. According to this theory, the consumer decision process starts from need identification, gathering of relevant information, pre-purchase evaluation of product attributes and alternatives, consumer purchase decision, consumption, post-consumption evaluation, and divestment. The first stages in the consumer decision-making process aid in identifying and satisfying the consumer's needs and wants. The second stage is to embark on an information search. The third stage is the evaluation of product attributes and alternatives to establish purchase intention. A consumer purchase intention influences the actual consumer purchase decision, which is the fourth stage in the consumer decision-making process. Consumption is the fifth stage, while post-consumption evaluation, which culminates into satisfaction or dissatisfaction, is the sixth stage. The seventh stage in the decision-making process is divestment, which acknowledges if the product purchased and consumed will be disposed of or not. Relating this theory to the study entails that consumer purchase decision, which is the dependent variable of this study, stems from the fourth stage of this theory and also is rooted in it.

Source: Blackwell et al. (2005).

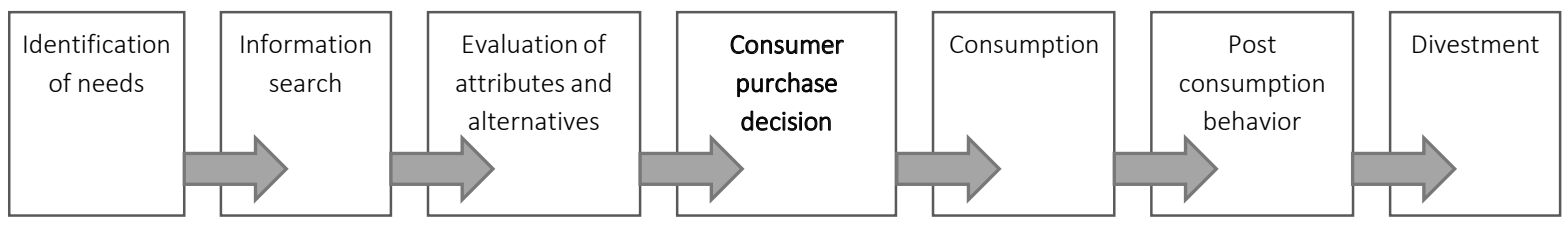

Figure A1. Consumer purchase decision process 


\section{APPENDIX B}

\section{QUESTIONNAIRE FOR THE SURVEY AND RESPONDENTS' RESPONSES FREQUENCY}

Instruction: This questionnaire is meant for respondents who take malt drinks only

\section{Screening Questions:}

Do you drink malt?

1. Yes [356] 2. No [0]

Please proceed if your answer to question 'a' is 'Yes'

For how long?

1. Below one year [0] 2. More than one year [356]

Among the selected malt brands under investigation, which brand do you prefer most?

1. Grand Malt [45] 2. Amstel Malta [93] 3. Maltina [72] 4. Guinness Malt [88] 5. Dubic Malt [58]

d. What type of malt consumer are you?

1. Working day drinker [83] 2. Working night drinker [68]3. Weekend day drinker [46] 4. Weekend night drinker [42] 5. Anytime heavy drinker [101] 6. Anytime casual drinker [14] 7. Occasional drinker [2]

\section{SECTION A: PERSONAL DEMOGRAPHIC DATA AND GENERAL INFORMATION}

Instruction: please tick $(\sqrt{ })$ in the space provided beside each question \& fill in appropriate answer.

Gender:

1. Male [121] 2. Female [235]

Marital Status:

1. Single [238] 2. Married [112] 3. Divorced [4] 4. Widowed [2]

Age Range:

1. Below 18 years [0] 2. 18-30 years [148] 3. 31-40 years [113] 4. 41-50 years [66] 5. Above 50 years [29]

Average Monthly Income Range:

1. Below $\$ 18,000$ [5] 2. $\$ 18,000-\$ 38,999$ [60] 3. $\$ 39,000$ - $\$ 69,999$ [82] 4. $\$ 70,000$ - $\$ 99,999$ [102] 5 .

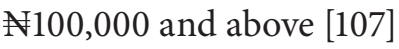

Key for Evaluation: Multisensory Attributes Scale

1. $\mathbf{N M P}=$ Not at all important 2. SMP $=$ Slightly important 3. SWMP $=$ Somewhat important

4. $\mathbf{V M P}=$ Very Important 5. EMP = Extremely important.

Key for Evaluation: Consumer Purchase Decision Scale

1. DNPUR $=$ Definitely not purchase 2. NPUR $=$ Not purchase 3. NEU $=$ Neutral 4. $\mathbf{P U R}=$ purchase

5. DPUR= Definitely purchase. 


\section{SECTION B: MULTISENSORY MALT ATTRIBUTES SCALE}

Instruction: please tick $(\sqrt{ })$ by showing the extent to which these items are important or not important to you concerning sensory attributes of your brand of malt.

\begin{tabular}{|c|c|c|c|c|c|c|}
\hline Items & Malt Brand Visual Attributes $\left(X_{1}\right)$ & $E M P=5$ & $\mathrm{VMP}=4$ & SWMP = 3 & SMP $=2$ & NMP $=1$ \\
\hline Vis 1 & $\begin{array}{l}\text { Of what importance is the color of your preferred malt } \\
\text { brand bottle/can/pack when making purchase decision? }\end{array}$ & 130 & 116 & 53 & 44 & 13 \\
\hline Vis 2 & $\begin{array}{l}\text { How important is the size of your preferred malt brand } \\
\text { bottle/pack/can while making purchase decision? }\end{array}$ & 116 & 134 & 50 & 40 & 16 \\
\hline Vis 3 & $\begin{array}{l}\text { Of what importance is the appearance of your favorite } \\
\text { malt brand bottle/pack when making purchase decision? }\end{array}$ & 121 & 141 & 35 & 41 & 18 \\
\hline Vis 4 & $\begin{array}{l}\text { How important is the shape of your desired malt brand } \\
\text { bottle/can/pack while making purchase decision? }\end{array}$ & 58 & 61 & 140 & 58 & 39 \\
\hline Vis 5 & $\begin{array}{l}\text { How important is the design of your preferred malt brand } \\
\text { bottle/can/park while making purchase decision? }\end{array}$ & 135 & 153 & 43 & 25 & 0 \\
\hline \multicolumn{7}{|c|}{ Malt Brand Gustatory Attributes $\left(X_{2}\right)$} \\
\hline Gus 1 & $\begin{array}{l}\text { Of what importance is the quality taste of your favorite } \\
\text { brand of malt while making purchase decision? }\end{array}$ & 194 & 124 & 25 & 12 & 1 \\
\hline Gus 2 & $\begin{array}{l}\text { How important is the low sugar taste of your preferred } \\
\text { brand of malt while making purchase decision? }\end{array}$ & 221 & 115 & 11 & 9 & 0 \\
\hline Gus 3 & $\begin{array}{l}\text { Of what importance is the sweet taste of your desired malt } \\
\text { brand while making purchase decision? }\end{array}$ & 72 & 94 & 59 & 109 & 22 \\
\hline Gus 4 & $\begin{array}{l}\text { How important is the cream taste of your preferred malt } \\
\text { brand when making purchase decision? }\end{array}$ & 97 & 164 & 73 & 13 & 9 \\
\hline Gus 5 & $\begin{array}{l}\text { Of what importance is the sucrose taste of your malt brand } \\
\text { choice when making purchase decision? }\end{array}$ & 138 & 134 & 61 & 20 & 3 \\
\hline \multicolumn{7}{|c|}{ Malt Brand Tactile Attributes $\left(X_{3}\right)$} \\
\hline Tac 1 & $\begin{array}{l}\text { How important is the feel of malt brand bottle/pack/can } \\
\text { while making purchase decision? }\end{array}$ & 99 & 150 & 46 & 51 & 10 \\
\hline Tac 2 & $\begin{array}{l}\text { How important is the weight of your preferred malt brand } \\
\text { bottle/pack/ can when making purchase decision? }\end{array}$ & 84 & 130 & 52 & 76 & 14 \\
\hline Tac 3 & $\begin{array}{l}\text { Of what importance is the chillness of your desired malt } \\
\text { brand bottle/can/pack while making purchase decision? }\end{array}$ & 120 & 153 & 42 & 38 & 3 \\
\hline Tac 4 & $\begin{array}{l}\text { How important is the glossiness of your favorite brand of } \\
\text { malt bottle/can/pack while making purchase decision? }\end{array}$ & 82 & 79 & 99 & 71 & 25 \\
\hline Tac 5 & $\begin{array}{l}\text { How important is the smoothness of your preferred malt } \\
\text { brand bottle/can/pack when making purchase decision? }\end{array}$ & 77 & 139 & 43 & 69 & 28 \\
\hline \multicolumn{7}{|c|}{ Malt Brand Olfactory Attributes $\left(X_{4}\right)$} \\
\hline Olf 1 & $\begin{array}{l}\text { How much importance is the pleasant smell of your } \\
\text { preferred malt brand when making purchase decision? }\end{array}$ & 112 & 138 & 65 & 32 & 9 \\
\hline Olf 2 & $\begin{array}{l}\text { Of what importance is the flavor your favorite brand of } \\
\text { malt while making purchase decision? }\end{array}$ & 171 & 144 & 27 & 13 & 1 \\
\hline Olf 3 & $\begin{array}{l}\text { What importance do you attach to the aroma of your } \\
\text { desired malt brand when making purchase decision? }\end{array}$ & 104 & 139 & 75 & 24 & 14 \\
\hline Olf 4 & $\begin{array}{l}\text { Of what importance is the fragrance smell of your } \\
\text { preferred malt brand while making purchase decision? }\end{array}$ & 105 & 138 & 31 & 61 & 21 \\
\hline \multirow[t]{6}{*}{ Olf 5} & $\begin{array}{l}\text { How do you value the pleasant odor of your preferred } \\
\text { brand of malt when making purchase decision? }\end{array}$ & 108 & 145 & 63 & 21 & 19 \\
\hline & $\begin{array}{l}\text { Rank the relevance of the following variables in order } \\
\text { of importance while making purchase decisions for a } \\
\text { particular brand of malt }\end{array}$ & $1^{\text {st }}$ & $2^{\text {nd }}$ & $3^{\text {rd }}$ & $4^{\text {th }}$ & Rank \\
\hline & Visual & 15 & 12 & 38 & 7 & $3^{\text {rd }}$ \\
\hline & Gustatory & 109 & 39 & 2 & 0 & $1^{\text {st }}$ \\
\hline & Tactile & 7 & 8 & 5 & 17 & $4^{\text {th }}$ \\
\hline & Olfactory & 28 & 51 & 16 & 2 & $2^{\text {nd }}$ \\
\hline
\end{tabular}




\section{SECTION C: CONSUMER PURCHASE DECISION SCALE}

Please tick $(\sqrt{ })$ by showing the extent to which these items reflect your purchase decision of a particular brand of malt drink in relation to its sensory attributes.

\begin{tabular}{|c|c|c|c|c|c|c|}
\hline \multicolumn{2}{|r|}{ Consumer Purchase Decision $(Y)$} & \multirow{2}{*}{$\frac{\text { DPUR } 5}{102}$} & \multirow{2}{*}{$\begin{array}{c}\text { PUR } 4 \\
131\end{array}$} & \multirow{2}{*}{$\frac{\text { NEU } 3}{56}$} & \multirow{2}{*}{$\frac{\text { NPUR } 2}{47}$} & \multirow{2}{*}{$\frac{\text { DNPUR } 1}{20}$} \\
\hline CPD 1 & $\begin{array}{l}\text { Do you purchase a particular brand of malt drink } \\
\text { because of its visual (sight) attributes? }\end{array}$ & & & & & \\
\hline CPD 2 & $\begin{array}{l}\text { Do you purchase your preferred brand of malt drink } \\
\text { because of its gustatory (taste) properties? }\end{array}$ & 130 & 120 & 54 & 35 & 17 \\
\hline CPD 3 & $\begin{array}{l}\text { Do you purchase your favorite brand of malt drink } \\
\text { because of its tactile (texture) attributes? }\end{array}$ & 102 & 120 & 35 & 52 & 47 \\
\hline CPD 4 & $\begin{array}{l}\text { Do you purchase your desired brand of malt drink } \\
\text { because of its olfactory (smell) properties? }\end{array}$ & 98 & 117 & 64 & 50 & 27 \\
\hline
\end{tabular}

\section{APPENDIX C}

Distribution and return of the copies of the questionnaire

\begin{tabular}{|c|c|c|c|c|}
\hline No. & Name of the selected sales outlets & Copies distributed & Valid copies & $\begin{array}{l}\text { Unreturned/ } \\
\text { invalid copies }\end{array}$ \\
\hline 1 & Vegas restaurant Abakaliki & 8 & 7 & 1 \\
\hline 2 & New Jerusalem Bar Abakaliki & 8 & 8 & 0 \\
\hline 3 & Crunches Fried Chicken Restaurant Abakaliki & 9 & 8 & 1 \\
\hline 4 & Brifina Bar Abakaliki & 7 & 6 & 1 \\
\hline 5 & Nwanyilga Restaurant \& Bar Abakaliki & 9 & 8 & 1 \\
\hline 6 & MR Biggs Fast Food Joint Abakaliki & 8 & 8 & 0 \\
\hline 7 & FriendzRendezous Bar Abakaliki & 6 & 6 & 0 \\
\hline 8 & Nourisher Continental Fast Food Awka & 8 & 8 & 0 \\
\hline 9 & Ofiaku Kitchen \& Bar Awka & 10 & 9 & 1 \\
\hline 10 & Lass-Bejoy Bar Awka & 13 & 13 & 0 \\
\hline 11 & Mummy's Pot \&CruisineAwka & 8 & 8 & 0 \\
\hline 12 & Rose-Life Restaurant Awka & 8 & 7 & 1 \\
\hline 13 & Cofi Premium Bar \& Lounge Awka & 12 & 11 & 1 \\
\hline 14 & Next Level Bar Awka & 7 & 7 & 0 \\
\hline 15 & Cabrini Bar Enugu & 17 & 15 & 2 \\
\hline 16 & Ejindu Restaurant Enugu & 14 & 13 & 1 \\
\hline 17 & Crunches Fast Food Enugu & 15 & 13 & 2 \\
\hline 18 & Dolphine Restaurant Enugu & 13 & 11 & 2 \\
\hline 19 & Emily African Continental Restaurant Enugu Amazon Bar Enugu & 15 & 14 & 1 \\
\hline 20 & Amazon Bar Enugu & 10 & 9 & 1 \\
\hline 21 & Platinum Bar Enugu & 12 & 12 & 0 \\
\hline 22 & Kilimanjaro Fast Food Joint Owerri & 10 & 10 & 0 \\
\hline 23 & Owerri Club, Restaurant \& Bar & 13 & 12 & 1 \\
\hline 24 & Golden Bites Restaurant \& Bar Owerri & 10 & 9 & 1 \\
\hline 25 & Cubana Restaurant \& Bar Owerri & 12 & 11 & 1 \\
\hline 26 & Mimi Place Bar Owerri & 14 & 13 & 1 \\
\hline 27 & Villa City Bar Owerri & 16 & 14 & 2 \\
\hline 28 & California Bar Owerri & 13 & 13 & 0 \\
\hline 29 & Hoffers Fast Food Joint Umuahia & 10 & 10 & 0 \\
\hline 30 & La Fame Restaurant \& Bar Umuahia & 12 & 11 & 1 \\
\hline 31 & Exclusive Restaurant \& Bar Umuahia & 9 & 8 & 1 \\
\hline 32 & De Latinos Bar Umuahia & 11 & 9 & 2 \\
\hline 33 & Network Restaurant \& Bar Umuahia & 14 & 13 & 1 \\
\hline 34 & D Place Bar Umuahia & 12 & 12 & 0 \\
\hline \multirow[t]{3}{*}{35} & Chops Galaxy Bar Umuahia & 11 & 10 & 1 \\
\hline & Grand total & 384 & 356 & 28 \\
\hline & Percent & 100 & 92.7 & 7.3 \\
\hline
\end{tabular}

